\title{
TRILÓGIA MAROŠA KRAJŇAKA ${ }^{1}$
}

V príspevku analyzujem prózy Carpathia, Entropia a Informácia od slovenského spisovatel'a zo strednej generácie Maroša Krajňaka. Kombinovaním dokumentárnych a fiktívnych motívov a postáv, ako aj realistických, lyrických a magickorealistických naratívnych postupov spisovatel' v tejto svojráznej trilógii rekonštruuje postupný, no nezastavitel'ný proces zániku Rusínov, malého slovanského národa obývajúceho časti územia dnešného Slovenska, Pol'ska a Ukrajiny. Zo žánrového aspektu ide o autobiografické prózy, miestami s prvkami cestopisu alebo reflexívnej eseje. Dominujú v nich nostalgické spomienky narátora na detstvo, ktoré neraz nadobúdajú groteskný, vo svojej podstate i deziluzívny pohl'ad na zobrazovanú skutočnost'. Takúto mozaiku motívov, naratívnych postupov a stratégií homogenizujú esejisticky skoncipované časti textu, reflektujúce javy, ktoré poznačili nielen dejiny tohto národa, ale aj novšie dejiny Európy.

Klúčové slová: Maroš Krajňak, trilógia, Rusíni, dokumentárnost', lyrizácia, magický realizmus, autobiografia, cestopis, esej.

The paper analyzes the novels Carpathia, Entropia and Informacia written by the Slovak writer of middle generation Maroš Krajňak. Using a combination of documentary and fictitious motifs and characters, as well as realistic, lyrical and magic-realistic narrative techniques, in this trilogy of a sort the writer reconstructs a gradual, yet unstoppable process of the disappearance of Ruthenians, a small Slavic nation settled on the borders of Slovakia, Poland and Ukraine. As for the genre, this prose is basically autobiographic with elements of travel writing and a meditative essay. The novels are dominated by nostalgic memories of childhood, which often assume a grotesque and essentially a disillusionary view of reality. Such a mosaic of narrative techniques and strategies are homogenized by essayistic parts of the text, where Krajňak analyzes the phenomena that marked not just the history of these people, but also the recent history of Europe.

Keywords: Maroš Krajňak, trilogy, Ruthenians, documentary, lyricization, magic realism, autobiography, travel writing, essay.

Hlavná „postava“ trilógie Maroša Krajňaka (1972, Svidník), ktorú tvoria prózy Carpathia (2011), Entropia (2012) a Informácia (2013), je metaforická Krajina-geograficko-toponymicky a politicko-štátne len načrtnuté (juhovýchod Pol'ska, východ Slovenska, západ Ukrajiny), presne nevyhranené územie, v románoch pomenované najčastejšie Zóna, Halič, Carpathia či Florinská monarchia. To, čo najviac vymedzuje a homogenizuje túto Krajňakovu Krajinu a vo vel'kej miere spája jeho texty do trilógie, sú Rusíni, národ, ktorý na jej území žije alebo v minulosti žil, no ktorý v súčasnosti postupne a nezastavitel'ne speje k svojmu zániku. Romány sú sčasti poznačené autoštylizáciou a rozprávanie sa najčastejšie uskutočňuje z pozície „márnotratného syna“, ktorý sa, hladajúc seba, vlastnú identitu či identitu svojho národa,

${ }^{1}$ Príspevok vznikol v rámci projektu číslo 178017 Diskurzy menšinových jazykov, literatúr a kultúr v juhovýchodnej a strednej Európe, ktorý financuje Ministerstvo vedy a školstva Srbska. 
vracia „zo sveta“ (Bratislava) domov, do rodiska a pritom sa usiluje pochopit', uchopit' a zachovat' tento radikálne sa meniaci svet. Na tieto ciele autor využíva rozličné naratívne prvky, postupy a stratégie: od dokumentárno-publicistických cez esejisticko-reflexívne až po mýticko-legendické, lyrizujúce a nie na poslednom mieste i surrealistické a magickorealistické. Zapája sa tak do ústredného prúdu súčasnej slovenskej prózy, ktorá sa na začiatku 21. storočia rozličnými, často „rozchádzajúcimi sa cestičkami“, postupne, no nezastavitel'ne vzd'al'ovala od dominujúcej postmodernej poetiky z konca 20 . storočia. Tento Krajňakov literárny odklon možno označit' ako regionalizmus a vnímat' ho v kontexte poetologickej súdržnosti spisovatel'ov určitého regiónu, v tomto prípade východného Slovenska (Milan Zelinka, Stanislav Rakús, Václav Pankovčín a i.). Autori monografie Hladanie súčasnosti tento typ prózy definujú takto: „Pod pojmom regionalistická literatúra nechápeme kvalitatívne slabšiu tvorbu, zvyčajne aj svojou témou, prípadne jazykom (nárečie) obmedzenú na niektorú lokalitu, ale ten typ literatúry (prózy), ktorý kladie zvláśtny dôraz na geografický priestor ako jednu z dôležitých zložiek literárneho diela. V regionalistickej próze je zvýraznený vzt’ah priestoru ako čisto literárnej, teda fikčnej kategórie s nefikčným, 'skutočným' priestorom." (Passia a i. 2014: 68). Myslím si však, že prozaická tvorba Maroša Krajňaka znesie i označenie (novo)angažovanej literatúry, pojem dlhodobo ideologicky dehonestovaný, avšak v súčasnosti čoraz viac nahrádzajúci postojový defetizmus a skepsu postmoderného spisovatel'a, ale i jeho prvoradú zameranost' na textovú skutočnost'. To znamená, že Krajňak nachádza inšpiráciu pre svoju prozaickú tvorbu predovšetkým v empirickej realite, voči ktorej v románoch sústavne zastáva angažovaný, pritom výrazne kritický, neraz tiež ironický postoj, a to nielen voči súčasnej spoločensko-politickej (ne)usporiadanosti sveta, ale zvlášt' voči rozličným, vo svojej podstate archetypálnym prejavom l'udskej deštrukcie a zla.

Prvá čast' trilógie, román Carpathia, sa začína lyrizujúcim opisom Krajiny odpozorovanej z perspektívy rozprávača-motocyklistu. Krajinu, ktorou cestuje, skúma a zároveň sa s ňou zžíva: „Každou z nich prúdim a chcem, aby všetky prúdili vo mne.“ (Krajňak 2011: 5), rozprávač definuje ako Zóny ${ }^{2}$ 0, 1, 2, 3 a X, rozdelené na základe štátneho prináležania: 0 je pol'ská čast', 1,2 a 3 sú slovenské územia a X ukrajinská čast' takto vnímaných zón. Vymedzenie tejto Krajňakovej Krajiny je teda provizórne, jej hranice sú fluktuačné, nekryjú sa v úplnosti so štátnymi, ale sú určené predovšetkým prítomnostou Rusínov, ich jazykom, kultúrou a dejinami. ${ }^{3}$

Rozprávač na svojich potulkách oslovuje a fotografuje obyvatel'ov Krajiny, čím vlastne nostalgicky privoláva spomienky na detstvo a mladost'. Rekonštruuje tak minulost', predovšetkým vlastnú či rodinnú, ale i národnú, rusínsku. Týmto návratom do rodiska chce oživit' spomienky, uschovat' ich a upevnit' v pamäti a tak ich zachránit' pred nevyhnutným zánikom: „Zachytávam obrazy opustených domov, ktoré sa už čoskoro stratia. Teraz ma fascinujú. Neskôr sa k nim stále musím vracat'. V ich

${ }^{2}$ Nemožno si nevšimnút' alúziu na film Stalker od režiséra Andreja Tarkovského, s ktorým Krajňakovu prózu spája najmä románom evokovaná dystopická, postapokalyptická atmosféra. K tomuto režisérovi sa Krajn̆ak vracia aj neskôr, apostrofujúc jeho film Nostalgia, jednoznačne tak podčiarkujúc rozprávačov postoj či pocit k zobrazenej skutočnosti.

\footnotetext{
${ }^{3}$ Spisovatel' tento národ a jeho jazyk vo svojich románoch nikde priamo nepomenúva, čím chce zrejme naznačit', že ide o poslednú, „,mŕtvu fázu“ asimilácie a vyst’ahovania, teda odumierania tohto národa a jeho jazyka.
} 
zadebnených oknách vidím výčitku, že som sa nikdy nepozrel do vnútra. Mohol som ich útroby zachytit' v mojej mysli a neskôr znova premenit' na skutočnost'." (Krajňak 2011: 42). Postoj rozprávača k zanikajúcemu svetu Krajiny je teda v podstate dvojaký: na jednej strane záchranný, poznačený úsilím o skanzenizáciu, zakonzervovanie a trvalé zafixovanie tohto zanikajúceho sveta vo vlastných spomienkach, ale i v akejsi univerzálnej civilizačnej pamäti; no súbežne je i realisticko-pragmatický, uvedomujúci si nezastavitel'nost' zániku spôsobeného násilnou deportáciou, asimiláciou a emigráciou obyvatel'ov Krajiny i márnost' každého úsilia vynaloženého na jeho zastavenie, znemožnenie: „Redaktorovi niečo splietam o zastavenom vývoji, že toto je zbytočne nostalgické pripomínanie si už mŕtvej fázy, ktorú už dávno malo vystriedat niečo iné..." (Krajňak 2011: 52).

Východiskovú cestopisno-reportážnu perspektívu rozprávania, realizujúceho sa v prítomnom čase a v prvej osobe jednotného čísla, spisovatel' sústavne prerýva a kombinuje so spomienkovo-historickými pasážami, a to najmä takým spôsobom, že vonkajšia skutočnost', príroda a l'udia, s ktorými sa narátor stretáva, u neho asociačne vyvolávajú rozličné reminiscencie na minulost', blízku alebo d’alekú, osobnú, no tiež históriu Krajiny a jej obyvatel'ov, v ktorých sa rozprávač či spisovatel' demiurg neraz reinkarnuje (do strýka, otca, pastiera či iných postáv), preberajúc aj ich perspektívu nazerania na skutočnost'. Tieto príbehy Maroš Krajňak v sujetotvorbe románu upravuje a spája predovšetkým podl'a princípov filmového strihu, vytvárajúc tak svojráznu kaleidoskopickú literárnu mozaiku, akýsi trojrozmerný obraz zanikajúcej Krajiny: „Som ako skutočný Stalker, ktorý sa po dlhom čase vrátil zo Zóny, a teraz nastupujúcim spánkom pretínam predchádzajúce vnímanie, aby sa takto do mňa dostal už dávno mŕtvy Tarkovskij. On mi s mojím predošlým dovolením skopíruje všetky závity a získané obrazy potom po zostrihani prenesie na svoj nový film." (Krajňak 2011: 98). Zrejmé však je, že príbehy utvárajúce tento základný sujetový rámec, majú v románe väčšinou „nebeletristické“, všedné, neraz až triviálno-bizarné motivačné východisko a takéto rozprávanie potom celkovo inklinuje $\mathrm{k}$ cestopisno-reportážnym, čiže $\mathrm{v}$ podstate publicistickým žánrom. Také sú najmä zobrazené udalosti a osobnosti súvisiace $\mathrm{s}$ rozprávačovým primárnym predsavzatím hl'adat' $\mathrm{v}$ Krajine materiálne pozostatky z druhej svetovej vojny pre Múzeum vojny, taký je aj výrazne deziluzívno-ironický opis jeho návštevy tradičnej folklórno-kultúrnej slávnosti Rusínov i jeho prítomnost' na grotesknej rekonštrukcii tzv. Karpatsko-duklianskej operácie pri oslobodzovaní Československa, také sú tiež jeho stretnutia a rozhovory s rozličnými reálne existujúcimi osobnost’ami Krajiny... Beletristicky atraktívnejšie, so zretel'nejším konfliktom a napätím, sú príbehy, inšpirované minulost’ou, dejinami Krajiny, predovšetkým tragickými udalost’ami z druhej svetovej vojny a tesne po jej ukončení, ktoré narátor rekonštruuje na základe svedectiev priamych účastníkov. Sú to príbehy súvisiace $\mathrm{s}$ nemeckou okupáciou i s viacnásobnými násilnými deportáciami jej obyvatel’ov, najmä však s vojnou vyvolanou nenávist'ou a násilím medzi jednotlivými národmi obývajúcimi toto územie. Na dané historické tematické východisko nadväzujú aj rozprávačove spomienky na vlastné detstvo a mladost', prežité v rodisku, takisto do značnej miery poznačené vojnovými udalost'ami, a to jednak priamo, prostredníctvom materiálnych pozostatkov z vojny (zbrane, uniformy, náboje, kosti mítvol atd'.), ktoré rozprávač nachádza, jednak cez starootcovské rozprávania o vojne, ktoré mu zostali natrvalo zafixované v pamäti. 
Obidve tematicko-motivačné paradigmy, teda prítomnostnú a minulostnú, sa autor sústavne usiluje ozvláštnit', „beletrizovat"،, najmä prostredníctvom lyrických postupov a prvkov, zvlášt' pri opisoch prírody Krajiny. V danom kontexte Krajňak využíva, nie vždy funkčne, mystifikáciu alebo perifrastický opis. Mám dojem, že Krajňak zvlášt' produktívne ozvláštňuje daný základný, v podstate bezkonfliktný príbeh rozprávača/hlavnej postavy vtedy, ked' využíva poetologické prvky a postupy magického realizmu, prejavujúce sa ako bytostné sklbenie reálneho a ireálneho či magického s empirickým. Tvorivé impulzy južnoamerického magického realizmu v románoch Maroša Krajňaka zaevidovali prakticky všetci ich interpretátori (Marta Součková, Vladimír Barborík, Radoslav Passia, Pavol Markovič a i.), rozširujúc ich aj o viac-menej kompatibilné postupy a znaky surrealizmu, naturizmu či o podobné tendencie v novšej ukrajinskej literatúre, prípadne o niektoré znaky l’udovej slovesnosti. Funkciu a význam magickorealistickej poetiky vo svojej tvorbe Krajňak priamo explikuje v poslednom románe trilógie Informácia: „Florinská monarchia, krajina bez žijúceho vladára, ty svojim obyvatel'om podsúvaš lyrické bludy, napriklad také, že flóra a fauna sú v podstate jedno, ked' zhynie živočích, znova sa vráti ako krásna rastlina a naopak. Alebo že každé svetlo prichádzajúce z neba má špecifickú chut' a zároveň vôňu, rozlíšit'sa dajú iba so zavretými očami, každý tvoj človek vie takto zo slnka dokonalou presnost'ou vyrátat' čas, dokáže hravo rozoznat' aj fázu luny, vie neomylne určit’ typ a názov každého vesmírneho objektu. Presvedčila si l’udí, aby neexistovali týždne a mesiace, každý deň má vždy úplne nový názov. V tebe sa dá žit' iba obstarožný magický realizmus, všetko mu podlieha, pokusy vymanit' sa z neho sa vždy končia fatálnym nezdarom, každá začatá skutočnost’ má v sebe niečo nezvyčajné.“ (Krajňak 2013: 11). Tento Krajňakov román, ale aj jeho d’alšie prózy ${ }^{1}$ však od magického realizmu diferencuje akási autorská „nedôslednost"، čiže očividná poetologická rozpoltenost' jeho sujetotvorby na magickorealistické zobrazenie Krajiny a publicisticky kreovaný obraz skutočnosti nachádzajúcej sa mimo nej.

Takáto tvorivá „rozdvojenost”“ je už menšia v druhom Krajňakovom románe Entropia, ktorý sa nesie prevažne práve v znamení magickorealistického, ale miestami i groteskného zobrazovania skutočnosti. Rozdiel medzi Carpathiou a Entropiou vidno i v spôsobe rozprávania a koncipovania rozprávača. Zatial' čo v prvom Krajňakovom románe sa objavuje realisticky stvárnený rozprávač, ktorého mohol čitatel' stotožňovat' so samotným autorom, v Entropii sa hlavná dejová nit' uskutočňuje prostredníctvom dvoch breugelovsky vykreslených postáv, kamarátov Buka a Forela, ${ }^{2}$ ktorí sú hlavní fokalizátori deja a čitatel' sa na rozprávané príbehy pozerá najmä ich očami: „Niekto cudzí zakričal jediné nezrozumitel'né slovo a v očiach Buka a Forla sa objavuje nový dej. Oni ziskavajú spoločný, zjednotený zrak, ktorý sa teraz ocitá v d'alekej dedine. " (Krajňa 2012: 10). Schopnost' týchto postáv prestupovat' l'ubovol'ne v čase a priestore autor neraz využíva vo svojej sujetotvorbe, no aj napriek tejto možnosti rozprávanie v Entropii už nemá taký výrazný cestopisno-reportážny

\footnotetext{
${ }^{4}$ Okrem už uvádzanej románovej trilógie publikoval Krajňak v roku 2016 román Pogodowitz, ktorý však tematicky už len okrajovo nadväzuje na jeho prvé tri prózy.

${ }^{5}$ Literárna kritika sa pokúsila nájst’ i hlbšiu symboliku v menách týchto dvoch postáv, no nazdávam sa, že tu ide o „dvojjedinú“ postavu, s dôrazom na jej očividnej prostoduchosti, miestami až naivity ako výrazu „nevinnosti“, s iba ktorou možno čelit’ archetypálnemu zlu, proti ktorému $\mathrm{v}$ románe bojuje.
} 
ráz ako v Krajňakovom debute, ale sa značne „beletrizuje” a nadobúda i niektoré typické znaky románu cesty, teda literárneho zobrazenia cestovania postáv s vopred stanoveným ciel'om, najčastejšie s predsavzatím uskutočnit' nejaké dôležité životné poslanie. Zatial' čo v prvom Krajňakovom texte rozprávač zároveň i hlavná postava cestovala bežnými dopravnými prostriedkami (bicykel, motocykel, auto či vlak), v románe Entropia je pohyb Buka a Forela prinajmenšom netradičný, neraz i fantastický: tieto postavy síce cestujú predovšetkým pešo, ale nereálne rýchlo bežia, niekedy napríklad i na pásovom stroji, ktorý t’ahá vlečku, potom na obrovskom hadovi, oranžových koňoch alebo chrbtoch dvoch bačových psov...

Východiskový príbeh v románe Entropia, koncipovaný zrejme na dokumentárnom podklade, pramení v medzietnickom pogrome, ktorý sa odohral počas druhej svetovej vojny v ukrajinskej dedinke Kurdybanivka. Tento príbeh nadobúda fantastický ráz prostredníctvom zobrazenia jedného z priamych účastníka tejto tragickej udalosti, ktorý sa po smrti reinkarnuje $\mathrm{v}$ prešovskom čudákovi Pepovi. V tomto podstatnom motíve autor rozvádza základnú myšlienku v románe, tézu o archetypálnej podstate zla, čiže o jeho odvekej a nepretržitej prítomnosti v človekovi: „Pepo je preto prítomný v každom človeku a v každom z nich aj zostane." (Krajňak 2012: 18). Postavy Buko a Forel majú zistit', akým spôsobom sa táto nepretržitost' zla uskutočňuje, čo ju umožňuje. Aby vyriešili túto záhadu, cestujú do Kurdybanivky, jedinou obyvatel'kou ktorej je starena, Pepova manželka. Tajomstvo Pepovho prevtelenia im však neprezradí ona, ale Simon Wiesental, ${ }^{1}$ chýrny židovský lovec nacistov: spočíva v odvare - elixíre získanom z krvavej katovej sekery, ktorý vrah sústavne pije a tak sa obrodzuje, čiže získava nesmrtel'nost'.

Aj napriek autorovmu úsiliu evokovat' sústavnejšie ako v predošlom románe magickorealistickú Krajinu nadobúda zobrazovaná skutočnost' i v tomto románe namiesto magickej miestami akúsi bizarno-grotesknú podobu. Také sú vo vel'kej miere udalosti odohrávajúce sa v meste, čiže Prešove (vyčíňanie učňov, burleskný opis reprodukcie porno filmu, groteskný príbeh s travestítom a podobne), no taká je najmä čast' románu pomenovaná sitkom New Galicia No. X., ktorej dej zobrazuje americký osud vyst'ahovalcov z Krajiny, pričom primárny je ironicko-satirický tón rozprávania, potláčaný stereotypnost'ou a nezáživnost'ou udalostí príbehu. Podobne ako v predošlom románe aj tu sa autor usiluje za každú cenu ozvláštnit' všedný príbeh a často využíva perifrázy; namiesto bežného priameho pomenovania javu využije „ozvláštňujúci“, no často i banálny opis: „To, čo v ňom zostalo neovládatelné, sa teraz dostáva von cez jeho drobné oči. Tie sa najprv rýchlo sformovali do nového tvaru, akoby náhle narástol ich objem a ich jamky to nedokázali prijat. Potom sa však všetko upokojilo, Vnukove oči sa zahlbili spät’ do hlavy, ktorá teraz rozmýšla nad možnost’ou vediet'o žijúcom Weinbergerovi viac." (Krajňak 2012: 42). Na rozdiel od postupov dekompozície a mozaikovitosti, ktoré Krajňak primárne využíval vo svojom debute, v Entropii Krajňak už buduje pevnejšiu naratívnu štruktúru s výraznejšou ústrednou dejovou líniou. Žánrovo je tento román tiež jednoznačnejšie koncipovaný a popri znakov románu cesty a historického románu v ňom možno zaregistrovat'

${ }^{6}$ Okrem Wiesentala, narodeného v blízkosti Kurdybanivky, autor zapája do svojich príbehov aj iné historické postavy, ktoré sa viažu k územiu Krajiny; taký je napríklad John von Neumann, vedec židovského pôvodu, jeden z konštruktérov atómovej bomby alebo známy umelec Andy Warhol. 
aj znaky vedeckej fantastiky, najmä v závere. Očividné však je, že románový príbeh má len navonok pozitívny spád a za prvoplánovým happy endom sa skrýva trpká irónia, až sarkazmus, čo je ešte zjavnejšie v kontexte celkového dystopického koncipovania Krajňakovej románovej trilógie, evokujúcej nezastavitel'nost' entropie, čiže zvyšovania sa neusporiadanosti sveta. V takomto kontexte možno interpretovat' najmä burleskne zobrazené udalosti na konci románu, kde hlavné postavy Buko a Forel prostredníctvom eucharistie, realizujúcej sa za pomoci vína a keksov najprv znemožnia šírenie zla a následne vrátia postavu Pepa, stelesnenie zla, do detstva, „nevinného“ začiatku života, pričom im „pomáha“ singularita, vyvolaná pohanským bohom Perúnom: „Počas predchádzajúceho prerodu sa zmenil aj Pepov tien̆ a je z neho znova človek. Je to malý Pepo, možno šestročný chlapec, stojí na moste a s ním sa tu objavuje aj jeho matka a otec." (Krajňak 2012: 143).

Príbeh v tretej časti Krajňakovej trilógie, v románe Informácia ${ }^{2}$, začína opisom firemného zájazdu v horskom hoteli, na ktorom sa zúčastňuje aj hlavná postava v románe, Fedy. Je to kulminácia Fedyho hladania seba či svojho životného rámca, poznačeného rozčarovanost'ou, zhnusením, vyprázdnenostou, nudou... Táto udalost' je príležitostou, aby sa Fedy pozastavil a zamyslel nad sebou a svojím dovtedajším životom. Rozprávanie sa tak v d'alšich kapitolách románu sústred'uje na svojráznu rekonštrukciu Fedyho životnej cesty, jeho hl'adania seba a miesta vo svete či v spoločnosti. V rozvíjani príbehu spisovatel uplatňuje narativne postupy typické pre žáner vývojového románu, ktoré však postupne nadobúdajú aj znaky iniciačného románu. Vidno to najmä $v$ závere tejto prózy, kde autor zobrazuje radikálny prerod hlavnej postavy, ktorá sa po dlhom blúdení a hladani poznačenom pocitom márnosti a životnej porážky vzdáva dovtedajšieho (spôsobu) života, ${ }^{3}$ vracia sa do rodiska, do virtuálno-konkrétnej Florinskej monarchie, ${ }^{4}$ prekonáva životnú krízu a tak nachádza východisko zo životného labyrintu.

Najväčšiu čast' románu Informácia teda zaberá určitá rekapitulácia Fedyho prejdenej životnej cesty, ktorá začína jeho odchodom (vlakom) z rodiska, z provincie na východnom Slovensku a príchodom na štúdiá do vel'kého mesta, zrejme do Bratislavy. V tejto časti príbehu spisovatel' zobrazuje študentský život v ,internátnej liahne ničoty" (Krajňak 2013: 35), poznačený celkovou nízkou úrovňou štúdia, nehygienickými podmienkami v internáte, nezrelost’ou a najčastejšie i nezáujmom študentov o vzdelanie, ich permanentným opíjaním či sexuálnym hýrením. Narácia je $\mathrm{v}$ tretej osobe, ale fokalizátorom je Fedy a rozprávač evokuje jeho pocity nenaplnenosti, postojovej dezorientovanosti, no tiež revolty a vzbury. Svojráznou ilustráciou takto zobrazenej skutočnosti a následne i pocitov hlavnej postavy môže byt' v próze apostrofovaný film/,performancia“ dánskeho režiséra Larsa von Triera Idioterne, v ktorom mladí l'udia zámerne, teda provokačne napodobňujú „nenormálne“ či „idiotské“ správanie sa väčšiny „,normálnych“ ludí. Krajňakovo prozaické „imitovanie“ Trierovej sfilmovanej „performancie“, teda spisovatel'ove opisy bizarno-banálnych udalostí zo študentského života, bez výraznejšej tenzie a ironicko-satirického pri-

${ }^{7}$ O nadväznosti a vzt’ahu názvov románov Entropia a Informácia v kontexte súčasných vedeckých teórií dôkladne piše Pavol Markovič vo svojich interpretáciách Krajňakových próz.

${ }^{8}$ Pri rituáli iniciácie je to spravidla symbolická smrt' a následne znovuzrodenie.

${ }^{9}$ Krajňak si tu čiastočne vypožičiava názov štátneho útvaru Rusínov, ktorý pod názvom Florinská republika necelý rok existoval v oblasti dnešného juhovýchodného Pol'ska. 
farbenia, však často vyznievajú ošúchane, nudne, povrchne, teda vcelku míkvo a nezáživne. Autor sa síce aj tu, podobne ako vo svojich predošlých prózach, pokúsil rozprávanie o všedných, v podstate bezkonfliktných udalostiach ozvláštnit', no v modelovanom, urbánnom prostredí mohol len t’ažko na tento účel využívat' lyrizačné a magickorealistické prvky a postupy, bytostne prináležiace prírodnému prostrediu Florinskej monarchie. Krajňak tak znovu siaha predovšetkým po rozličných druhov perifrázy, ktoré však rozprávanie spravidla neozvláštňujú a neprehlbujú, ale skôr ho len významovo rozvodňujú a banalizujú.

Do tejto hlavnej dejovej línie zobrazujúcej osud Fedyho autor zapája aj príbeh jeho najlepšieho kamaráta Vaxa, ktorý však neštuduje, ale blúdi Európou a Amerikou hl’adajúc pracovné uplatnenie, ale ešte viac seba. Narácia o Vaxových potulkách nadobúda, okrem značnej klišéovitosti, neraz tiež bizarno-grotesknú podobu, najmä pri zobrazení jeho krátkotrvajúceho pobytu v Amerike, v návšteve u bratranca Ronalda. Po neúspešnej ceste do Ameriky sa Vaxo spolu s Fedym vracia do rodiska, do Krajiny, s predsavzatím „,stúpit’ do epicentra florinskej mágie“ (Krajňak 2013: 54). Ale po vcelku rozčarujúcich návštevách niektorých legendárno-mýtických florinských osobností Vaxo „konečne našiel hl’adané miesto“ (Krajňak 2013: 77) - natrvalo zakotví u strýka Michala a stáva sa pustovníkom. Fedy sa však vracia spät’ do civilizácie, skončí fakultu a zamestnáva sa v konzultačnej firme. Jeho rozčarovanost' $\mathrm{z}$ takéhoto života a takto usporiadanej spoločnosti je vyjadrená v časti s príznačným pomenovaním Hymnus na kokotizmus, ktorý však svojím moralizátorstvom a expresívnou patetikou pôsobí štýlovo nesúrodo, umelo. Zároveň je však v tomto texte vyjadrený pre románový príbeh dôležitý iniciačný zlom, teda smrt' „starého“ Fedyho a náznak jeho radikálnej životnej transformácie. Daná zmena sa prejaví v jeho definitívnom návrate do rodiska, do opusteného rodičovského domu a v rozhodnutí zostat' tu natrvalo žit': „(...)vzdal sa navždy sily mestského cynizmu, za to získal samozrejmý lyrizmus florinských Karpát." (Krajňak 2013: 117).

Aj v tomto Krajňakovom románe sa príbeh, aspoň navonok, končí happy endom, v „postapokalyptickej“ budúcnosti, v ktorej sú hlavné postavy, Fedy a jeho kamarát Vaxo, už stredovekí l'udia, pustovníci, ktorí konečne nachádzajú seba, vlastnú identitu a zmysel života, a to v návrate do prírody, ku svojim koreňom. Dokladom toho môže byt' aj ich nachádzanie symbolického svätého grálu, konkrétne cirkevných relikvií, ukrytých pred vojenským plienením. Takéto prvoplánové „ک̌t’astné“ ukončenie Informácie neprekvapuje, ked’že podobne sa končia aj predchádzajúce romány Krajňakovej trilógie. V kontexte súčasnej slovenskej prózy je takáto utopickost', podžáner sci-fi literatúry, príznaková, lebo väčšina súčasných spisovatel'ov (Peter Maczovszky, Viliam Klimáček, Ondrej Štefánik a iní), využívajúcich vo svojich prózach postupy (vedeckej) fantastiky, frekventovane zobrazujú dystopickú skutočnost'. Ked' však takýto Krajňakov „optimizmus“ vnímame v širších významových konotáciách jeho románovej trilógie, javí sa nám predsa len ako autorova irónia, miestami až drsný sarkazmus, zastierajúci výraznú dystopickú skutočnost' zobrazujúcu nezastavitel’nost' zániku nielen jedného národa, Rusínov, ich jazyka a kultúry, ale aj neúprosnost' zániku civilizácie: „Blizky zánik Florinskej monarchie je predzvestou agónie zvyšku sveta, po nej rovnako zaniknú všetky národy a d'alej všetky štáty, spoločenstvá l’udí sa na istý čas presunú do virtuality..." (Krajňak 2013: 11). 


\section{Literatúra}

Barborík, Vladimír. „Poznámky k súčasnej próze: súvislosti a tri knihy Maroša Krajňaka”. Romboid, 49, 5-6, 2014: 55-63.

Krajňak, Maroš. Carpathia. Bratislava: Trio Publishing, 2011.

Krajňak, Maroš. Entropia. Bratislava: Trio Publishing, 2012.

Krajňak, Maroš. Informácia. Bratislava: Trio Publishing, 2013.

Krajňak, Maroš: Pogodowitz. Bratislava: OZ BRAK, 2016.

Markovič, Pavol. „Maroš Krajňak: Carpathia.” (In:) TOP 5 (slovenská literárna a výtvarná scéna 2011 v odbornej reflexii). Prešov: FACE, 2013, 42-47.

Markovič, Pavol. „Maroš Krajňak: Entropia.” (In:) TOP 5 (slovenská literárna a výtvarná scéna 2012 v odbornej reflexii). Prešov: FACE, 2014, 40-45.

Markovič, Pavol. „Variácie a posuny v Karpatskej trilógii”. Romboid, 49, 5 - 6, 2014: 112-114.

Passia, Radoslav. „Problémy a kontexty jedného debutu”. Romboid, 47, 5 - 6, 2012: 120-123.

Passia, Radoslav, Taranenková Ivana. Hl'adanie súčasnosti. Slovenská literatúra začiatku 21. storočia. Bratislava: LIC, 2014.

Souček, Jakub. „Farebná próza”. RAK, 18, 10, 2013: 42-43.

Součková, Marta. „K poetike próz Maroša Krajňaka.” (In:) Studium CarpathoRuthenorum 2019. Štúdie z karpatorusinistky 11. Prešov: PU v Prešove - Centrum jazykov a kultúr národnostných menšín, Ústav rusínskeho jazyka a kultúry, 2019, s. 10-22.

Adam Svetlik

\section{TRILOGIJA MAROŠA KRAJNJAKA}

\section{Rezime}

U radu se analiziraju romani Carpathia, Entropia i Informacia slovačkog pisca srednje generacije Maroša Krajnjaka (Maroš Krajňak). Kombinovanjem dokumentarnih i fiktivnih motiva i likova, odnosno realističkih, lirskih i magičnorealističkih narativnih postupaka pisac u ovoj svojevrsnoj trilogiji rekonstruiše postepeni, no nezaustavljiv proces nestajanja Rusina, malog slavenskog naroda, nastanjenog na tromeđi sadašnje Slovačke, Poljske i Ukrajine. Sa žanrovskog aspekta ove proze imaju u osnovi autobiografski karakter sa elementima putopisa, ali i meditivnog eseja. U njima dominiraju nostalgične uspomene na detinjstvo, koje često poprimaju groteskni, u svojoj suštini deziluzivni pogled na prikazivanu stvarnost. Ovakav mozaik narativnih postupaka i strategija homogenizuju esejistički koncipirani delovi teksta, u kojima Krajnjak analizira pojave koje su obeležile ne samo istoriju ovog naroda, nego i noviju istoriju Evrope.

Ključne reči: Maroš Krajnjak, trilogija, Rusini, dokumentarnost, lirizacija, magijski realizam, autobiografija, putopis, esej. 